\title{
Enantiomerically Pure D-Phenylglycine Production using Immobilized Pseudomonas aeruginosa 10145 in Calcium Alginate Beads
}

\author{
Fábio O. M. Alonso, O. A. C. Antunes* and Enrique G. Oestreicher* \\ Instituto de Química, Universidade Federal do Rio de Janeiro, Cidade Universitária CT, \\ Bloco A, Lab. 536B and 641, 21949-900 Rio de Janeiro-RJ, Brazil
}

\begin{abstract}
Em trabalhos anteriores em nosso laboratório, uma cepa de Pseudomonas aeruginosa demonstrou ter atividade enzimática na conversão de arilaminonitrilas em D-amino ácidos. Essa atividade enzimática aumentou por indução de modo a produzir D-fenilglicina enantiomericamente pura a partir de 2-fenil-2-aminoacetonitrila. No presente trabalho, as melhores condições para essa transformação são descritas. Para aumentar o uso potencial desse biocatalisador, células de Pseudomonas aeruginosa 10145 foram envolvidas em alginato em forma de pequenas esferas. Duas concentrações diferentes de alginato foram usadas nesse processo. A morfologia das pérolas foi analisada via microscopia eletrônica de varredura (MEV). As pérolas com altas porosidades, formadas com 1,5\% de alginato de sódio conduziram às melhores conversões de 2-fenil-2-aminoacetonitrila em D-fenilglicina (20\%, 3,0 horas de reação e excesso enantiomérico superior a 98\%). Repetições em quatro bateladas consecutivas demonstraram a manutenção da atividade desse sistema catalítico.
\end{abstract}

In a preliminary work in our laboratory, a Pseudomonas aeruginosa strain was found to have enzymatic activity to convert arylaminonitriles into D-amino acids. This enzymatic activity was increased by induction to produce enantiomerically pure D-phenylglycine using 2-phenyl2-aminoacetonitrile as starting material. In this work, the best conditions leading to this transformation are described. In order to increase the biocatalyst potential use, cells of Pseudomonas aeruginosa 10145 were entrapped in calcium alginate gel beads. Two different concentration of sodium alginate were used to immobilize these cells. Beads morphology was demonstrated by scanning electron microscopy (SEM). The beads with higher porosity, formed with $1.5 \%(\mathrm{~m} / \mathrm{v})$ of sodium alginate led to the best conversion of 2-phenyl-2-aminoacetonitrile into D-phenylglycine (20\% of conversion, $3.0 \mathrm{~h}$ of reaction enantiomeric excess higher than $98 \%$ ). Recycling was performed in four repeated batch reactions, which proved the biocatalyst activity maintenance.

Keywords: biotransformation, nitrilase, amidase, nitrile, hydratase

\section{Introduction}

Non-proteinogenic aminated acids have been extensively reported as chiral synthons in pharmaceutical, food and agriculture industries. ${ }^{1-3}$ In recent years, they have been used in the synthesis of a variety of bioactive molecules, such as antibiotics, antivirals and chemotherapeuticals. ${ }^{4-6}$ The use of chemoenzymatic methods to obtain these molecules is a suitable alternative to conventional synthetic routes. Aminoacylases, hydantoinases, aminotransferases and amino acid desidrogenases have been used to obtain enantiomerically

*e-mail: enrique@iq.ufrj.br; octavio@iq.ufrj.br pure non-proteinogenic aminoacids ${ }^{7-9}$ however the use of isolated enzymes increases process costs. To overcome this problem a wide number of microorganisms have been used reducing costs significantly. ${ }^{10-12}$

Amino nitriles used as starting material can be converted to the corresponding enantiomerically pure amino acid by the action of nitrile hydratase/amidase or nitrilase enzymes (Figure 1). ${ }^{13,14}$ It has been shown that many fungi and bacteria strains, belonging to Fusarium, Aspergillus, Penicillium, Rodhococcus and Pseudomonas are able to hydrolyze nitrile containing compounds. ${ }^{15-17}$ Formation of an intermediate amide was not reported for nitrile conversions catalyzed by any of the above mentioned microorganisms. These 
<smiles>NC(Cl)c1ccccc1</smiles>

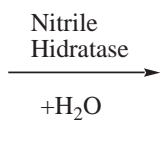<smiles>NC(=O)[C@H](N)c1ccccc1</smiles><smiles>NC(=O)[C@@H](N)c1ccccc1</smiles><smiles>N[C@H](C(=O)O)c1ccccc1</smiles><smiles>N#CC(N)c1ccccc1</smiles>
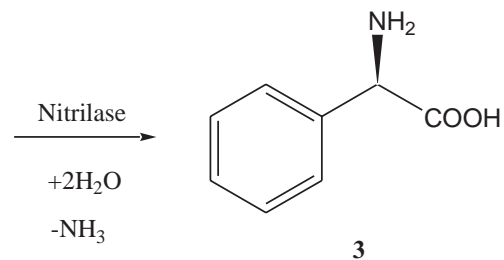

Figure 1. Synthesis of D-phenylglycine by nitrile hydrolyzing enzymes. 2-phenyl-2-aminoacetonitrile (1); 2-phenyl-2-aminoacetamide (2); D-phenylglycine (3).

observations suggest that these strains convert nitriles via the nitrilase pathway or the amidase activity is much higher than the hydratase activity. In yeast, nitriles are probably converted to the corresponding acid via the nitrile hydratase/amidase pathway. ${ }^{17}$

Microbial cell-catalyzed biotransformations of nitrile containing substrates occur effectively in free cell culture in suspension using different types of buffer as reaction media. The main inconvenience of this methodology is the reutilization or recycling ability of the biocatalyst since a decrease in enzymatic activity is a common fact in this case. ${ }^{11}$

The use of immobilized cells allows the repetitive use of the biocatalyst and it is a well fitted procedure to apply in continuous reactors and in scale-up planning. Encapsulation is one of the most important and reported techniques used to immobilize cells due to several reasons. ${ }^{18,19}$ One of the advantages is to segregate the biocatalyst from adverse environments. ${ }^{20}$ Carriers such as biopolymers beads can increase the ease of inoculants storage and handling and also reduce the chance of bioaerosol formation. ${ }^{21}$ Among many beads derived from diverse materials, the alginate bead is probably the most frequently used due to its non-toxic properties, easier handling, higher operational stability, easier cell separation and lower cost.

Alginates are unbranched binary co-polymers of $(1 \rightarrow 4)$-linked residues of $\beta$-D-mannuronic acid and
$\alpha$-L-guluronic acids. In aqueous solution, these polymers are converted to gels in the presence of multivalent cations (usually $\mathrm{Ca}^{2+}$ ). Gel entrapment occurs due to the ionic interaction between guluronic acid residues from two or more alginate chains and cations, yielding a three-dimensional network of alginate molecules. ${ }^{22}$

The aim of this study was to optimize the production of enantiomerically pure D-phenylglycine from 2-phenyl-2-amino-acetonitrile using calcium alginate beads entrapped with Pseudomonas aeruginosa as biocatalyst. Also to investigate the conditions of cell immobilization in different alginate concentrations, as well as, the alginate entrapped cells use in repeated batches for non-proteinogenic amino acid production.

\section{Materials and Methods}

\section{Chemicals}

Racemic phenylglycine nitrile, racemic and enantiomerically pure $L$ and $D$ phenylglycine and benzoic acid were purchased from Aldrich. Benzonitrile (technical grade) was purchased from Reagen. Other chemicals (of analytical grade) used for culture media were purchased from Difco, Vetec and BD.

\section{Pseudomonas strain}

Pseudomonas aeruginosa 10145 strain was kindly supplied by INCQS-FIOCRUZ-Rio de Janeiro, Brazil.

\section{Cell ressuspension}

The lyophilized cultures were ressuspended with saline solution under aseptical conditions, with sterile $\mathrm{NaCl}$ $0.85 \%(\mathrm{~m} / \mathrm{v})$. These cells suspensions were inoculated in solid Luria-Bertani (LB) media.

\section{Cell maintenance and biomass production}

The cells were maintained in $20 \%$ glycerol stocked at $-70{ }^{\circ} \mathrm{C}$. Cells stocks were transferred to solid LB media (Tryptone $1.0 \%$; yeast extract $0.5 \%$; $\mathrm{NaCl} 1.0 \%$ and agar $2.0 \%$ ) and incubated at $30{ }^{\circ} \mathrm{C}$ during $24 \mathrm{~h}$.

Colonies from solid media were collected and incubated under orbital agitation, in $250 \mathrm{~mL}$ conical flasks containing $50 \mathrm{~mL}$ of liquid Luria-Bertani (LB) sterile media (Tryptone $1.0 \%$; yeast extract $0.5 \%$ and $\mathrm{NaCl} 1.0 \%$ ) at $30{ }^{\circ} \mathrm{C}, 140 \mathrm{rpm}$ during $24 \mathrm{~h}$. Cell growth was monitored by turbity at $570 \mathrm{~nm}$. 
Nitrile hydrolysing activity

Cells were harvested by centrifugation at $4{ }^{\circ} \mathrm{C}$ and 4000 rpm for $15 \mathrm{~min}$. The biomass was ressuspended with 100 mmol L-1 phosphate buffer $\mathrm{pH} 7.0$ and transferred to 125 $\mathrm{mL}$ conical flasks containing a final volume of $25 \mathrm{~mL}$ of the same phosphate buffer. The biomass concentration in each flask was $500 \mathrm{mg}$ (wet weight) of cells per $25 \mathrm{~mL}$ of phosphate buffer.

To evaluate nitrile hydrolyzing activities, benzonitrile was used as a model substrate. Cells were incubated with 1.0 mmol L-1 of benzonitrile, under orbital agitation (140 rpm) at $30{ }^{\circ} \mathrm{C}$. Samples were periodically withdrawn and the cells were harvested by centrifugation. Biotransformation was evaluated by RP-HPLC, using a mobile phase containing methanol and water (70:30), flow rate at $0.8 \mathrm{~mL} \mathrm{~min}^{-1}$ and UV detector set at $247 \mathrm{~nm}$. Substrate consumption and benzoic acid production were measured.

\section{Activity induction procedure}

Pseudomonas aeruginosa cells were grown in LB media during 24 hours in the presence of benzonitrile $0.5 \%(\mathrm{v} / \mathrm{v}) ; 1.5 \%(\mathrm{v} / \mathrm{v})$ and $2.5 \%(\mathrm{v} / \mathrm{v})$, respectively. Since the addition of the inducer at the beginning of incubation led to inhibition of cell growth, benzonitrile was added to the culture in the stationary growth phase $(24 \mathrm{~h})$ at a concentration of $0.025 \%(\mathrm{v} / \mathrm{v})$. In this way, the inhibition of the cell growth by this compound was avoided. Cells were incubated during $24 \mathrm{~h}$ in the presence of the inducer.

\section{Immobilization in calcium alginate gel beads}

Entrapment of cells using calcium alginate was performed as follows: centrifuged cells, obtained after activity induction (500 $\mathrm{mg}$ wet weight) were mixed thoroughly with $20 \mathrm{~mL}$ of sterile sodium alginate, using two different concentrations ( 1.5 and $3.0 \% \mathrm{~m} / \mathrm{v}$ ). The mixture was extruded as drops into a solution of $0.1 \mathrm{~mol}$ $\mathrm{L}^{-1}$ calcium chloride using a $20 \mathrm{~mL}$ syringe. Bead size was controlled by the use of a hypodermic needle $(25 \times 5$ $\mathrm{mm}$ ) coupled to the syringe. The beads were cured and stored in $4{ }^{\circ} \mathrm{C}$ in the same solution for $2 \mathrm{~h}$, then washed three times with Tris- $\mathrm{HCl}$ buffer to remove the excess of cations and free cells.

The morphology of calcium alginate beads was checked by scanning electron microscopy (SEM). Samples were dried under vacuum in a glass desiccator and using silica as desiccant for $48 \mathrm{~h}$. Finally they were coated with gold and observed in the SEM (JEOL JSM-5610LV).
Production of enantiomerically pure D-phenylglycine

The biomass obtained with and without induction was harvested by centrifugation at $4{ }^{\circ} \mathrm{C}, 4000 \mathrm{rpm}, 15$ min, after growth in the previously described conditions. The biomass was suspended with $25 \mathrm{~mL}$ $100 \mathrm{mmol} \mathrm{L}^{-1}$ phosphate buffer $\mathrm{pH} 7.0$ to a final concentration of $500 \mathrm{mg}$ (wet weight) of cells per total volume of media. 2-Phenyl-2-amino-acetonitrile was added to the flasks to a final concentration of $1 \mathrm{mmol}$ $\mathrm{L}^{-1}$. Samples of $1.5 \mathrm{~mL}$ were periodically taken and the cells were harvested by centrifugation. The same methodology was used with immobilized cells, except that Tris HCL pH 7.0 was used as reaction media instead of phosphate buffer due to incompatibility of this latter with calcium alginate gel. The supernatant was then analyzed by chiral-HPLC.

Liquid Chromatography conditions and characterization of target product

Analytical HPLC was carried out in a Shimadzu LC10AS chromatograph. Analyses involving the use of benzonitrile as substrate were performed with a $250 \times 4.6$ mm Spherisorb ODS-2 C18 column, using methanol:water (70:30) as mobile phase $\left(0.8 \mathrm{~mL} \mathrm{~min}{ }^{-1}\right)$, UV detector set in $247 \mathrm{~nm}$. Analyses of 2-phenyl-2-amino-acetonitrile biotransformation were performed in a $250 \times 4.6 \mathrm{~mm}$ Nucleosil Chiral-1 column (Macherey-Nagel), using $\mathrm{CuSO}_{4} 1 \mathrm{mmol} \mathrm{L}^{-1}$ as mobile phase $\left(1.0 \mathrm{~mL} \mathrm{~min}{ }^{-1}\right), \mathrm{UV}$ detector was set in $240 \mathrm{~nm}$.

Polarimeter and infrared spectra analyses were conducted in a Perkim-Elmer 243B digital polarimeter and infrared spectra in a Perkin-Elmer 467 FTIR spectrometer, respectively. The reaction product was analyzed by GCMS after silanization. Silanization was performed as essentially described by Aquino Neto and co-workers. ${ }^{23}$ These latter analyses were performed in a HP 5890 series II gas chromatograph coupled to a HP 5972 mass spectrometer.

\section{Results and Discussion}

During a preliminary work not yet published, it was found that Pseudomonas aeruginosa 10145 strain was the most efficient microorganism tested for nitrile hydrolyzing activities with a model aromatic nitrile used as evidence for detecting such activities (benzonitrile). This strain can be considered as a good biocatalyst since it converted benzonitrile to benzoic acid, with maximum yield (70\% of conversion) in approximately $5 \mathrm{~h}$. 
No trace of the intermediate benzamide was detected in these experiments suggesting that the reaction may go through an enzymatic pathway involving nitrilase or by the bi-enzyme pathway constituted by nitrile hidratase/ amidase activities (Figure 1). In this latter case, the absence of amide is explained considering a much higher amidase activity than the nitrile hydratase activity.

In view of these results Pseudomona aeruginosa was chosen as a promising strain to be used for the synthesis of enantiomerically pure amino acids due to its high nitrile converting activities, therefore the production of enantiomerically pure D-phenylglycine from 2-phenyl2-amino-acetonitrile was attempted.

Synthesis of phenylglycine was performed by incubating Pseudomonas aeruginosa 10145 strain in L.B. medium as described in Material and Methods section, item 2.8. After $24 \mathrm{~h}$ when the culture was in the stationary phase, benzonitrile $0.025 \%$ was added as inducer and the culture was again incubated for $24 \mathrm{~h}$, when it reached stationary phase.

Target product was isolated from the reaction medium with slight modifications of the method described by Chilov et al. ${ }^{24}$ The medium was centrifuged in order to eliminate bacterial cells. The supernatant fluid was concentrated 5 fold under vacuum in rotatory evaporator. $\mathrm{pH}$ of this concentrated fluid, containing both the target product and the unreacted substrate, was adjusted to $\mathrm{pH}$ 9.0 with sodium carbonate on a ice bath. This medium was treated with the same volume of ethyl acetate in order to extract the residual substrate. The aqueous phase containing the amino acid was treated with $\mathrm{HCl} 0.05$ equiv. $\mathrm{L}^{-1}$ to lower the $\mathrm{pH}$ until $\mathrm{pH}$ 7.0. Finally this aqueous phase was evaporated to dryness, obtaining the amino acid in isolated form. This product was characterized as D-phenylglycine by several analytical methods. Polarimetry showed $[\alpha]_{D}^{25}=-158.8\left(\mathrm{c}=2, \mathrm{HCl} 3\right.$ equiv. $\left.\mathrm{L}^{-1}\right)$, a similar value was found in the literature under identical analysis conditions $\left([\alpha]_{\mathrm{D}}^{25}=155.0\right) .{ }^{9} \mathrm{FTIR}$ analysis revealed the following bands of axial deformation: $3439 \mathrm{~cm}^{-1}$ ( $\mathrm{N}-\mathrm{H}$ bond of $\left.\alpha-\mathrm{NH}_{3}^{+}\right) ; 2985$ and $2934 \mathrm{~cm}^{-1}(\mathrm{C}-\mathrm{H}$ bond of $\alpha-\mathrm{C}$ atom); $1612 \mathrm{~cm}^{-1}(\mathrm{C}=\mathrm{O}$ bond of $\mathrm{COOH}) ; 1395$ $\mathrm{cm}^{-1}$ (C-N bond); and 729 and $693 \mathrm{~cm}^{-1}$ bands of angular deformation of aromatic ring $\mathrm{C}-\mathrm{C}$ bonds. Very similar results characterizing this compound were reported in the literature. ${ }^{25}$ Finally by GC-MS, the silanized product showed $\mathrm{M}^{+}$at $m / 2,295$ for $\mathrm{C}_{14} \mathrm{H}_{25} \mathrm{NO}_{2} \mathrm{Si}_{2}$ and $m / z 280.0$ for $\mathrm{C}_{13} \mathrm{H}_{22} \mathrm{NO}_{2} \mathrm{Si}_{2}$.

A comparison of D-phenylglycine production was performed with induced and non-induced cells. As depicted in Figure 2, cells that were not induced with benzonitrile produced $18 \%$ of D-phenylglycine from the

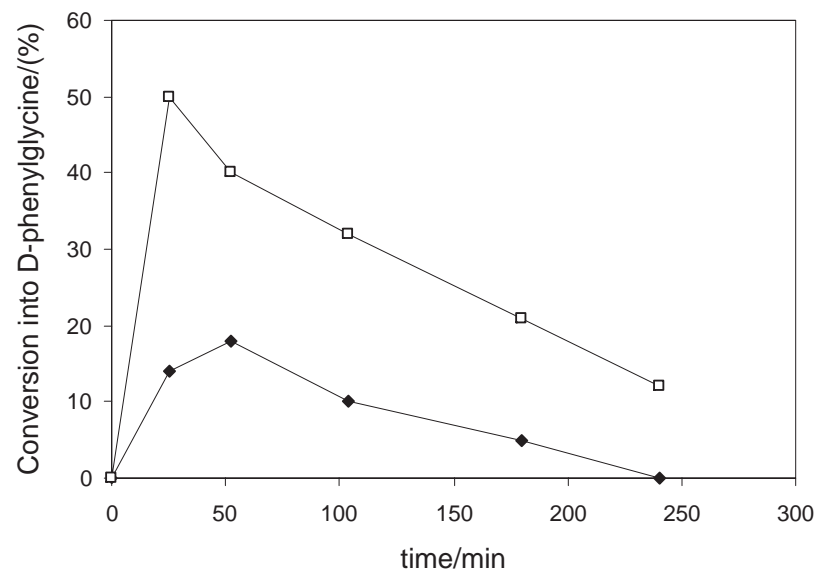

Figure 2. Induction of nitrile hydrolyzing activities in Pseudomonas aeruginosa 10145 by $0.025 \%(\mathrm{~m} / \mathrm{v})$ benzonitrile. ( $\square$ ) D-phenylglycine production in the presence of benzonitrile $0.025 \%(\mathrm{~m} / \mathrm{v})$. ( ) Dphenylglycine by not induced Pseudomonas cells.

nitrile after $60 \mathrm{~min}$ of reaction with an $e e=98 \%$. On the other hand cells treated with $0.025 \%(\mathrm{v} / \mathrm{v})$ benzonitrile were able to transform $50 \%$ of the nitrile substrate into the target product within $30 \mathrm{~min}$ of reaction with an identical $e e$. After the maximal conversion is reached a significant reduction of the product yield and of the remaining substrate concentrations (this latter data is not shown) occurred. These effects together with a parallel increase in turbidity (not shown) were taken as a strong indication that both the remaining substrate and the product were used by the cells as $\mathrm{C}$ and $\mathrm{N}$ sources to support cell growth.

As stated earlier induced Pseudomonas aeruginosa 10145 cells were able to transform $50 \%$ of the substrate into D-phenylglycine, which showed an $e e=98$. Sih and co-workers ${ }^{26}$ introduced an equation relating percentage of convertion, enantiomeric excess and selectivity factor useful for kinetic resolution of enantiomeric mixtures. A more complete and friendly method was introduced some years later by Machado et al. ${ }^{27}$ With both methods we could estimate that the selectivity factor must be a value between 73 and 100 .

Two different concentrations of sodium alginate solution $(1.5 \%$ and $3.0 \% \mathrm{~m} / \mathrm{v})$ were sterilized and used for the Pseudomonas aeruginosa entrapment, in order to investigate the effects on conversion rates. The morphologies of alginate beads containing entrapped cells after $2 \mathrm{~h}$ cured in calcium chloride $0.1 \mathrm{~mol} \mathrm{~L}^{-1}$ are shown in Figure 3A and 3B. They show that the porosity of the beads is greatly affected by the sodium alginate concentration, presenting a higher porosity when the more dilute solution of sodium alginate is use to form the beads.

The result obtained with cells entrapped in both types of alginate beads are shown in Table 1 (referred in terms of 
(A)
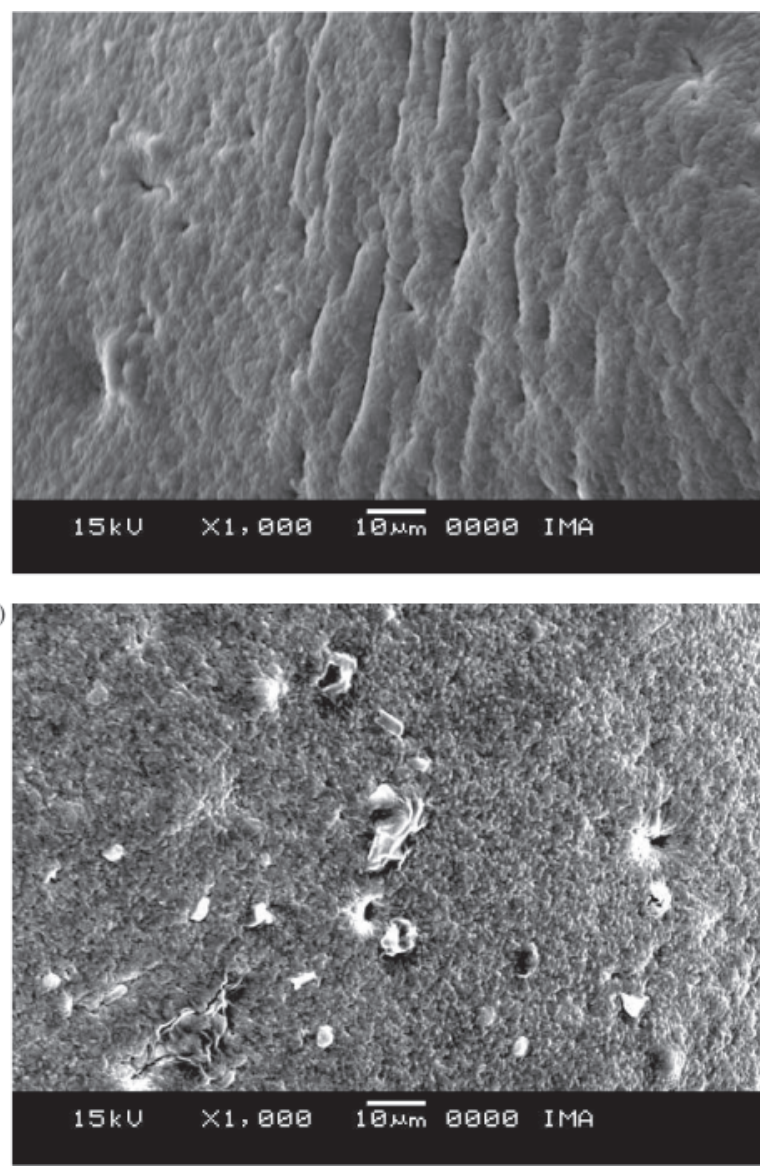

Figure 3. A: Surface morphology of calcium alginate bead obtained with $3.0 \%$ of sodium alginate; $3 \mathrm{~B}$ : Surface morphology of calcium alginate bead obtained with $1.5 \%$ of sodium alginate.

yields of D-phenylglycine and enantiomeric excess $(e e))$. This table shows that with the most porous beads, arising from the more dilute solution of sodium alginate $(1.5 \%$ $\mathrm{m} / \mathrm{v}$ ) used to form the beads, a maximum conversion of D-phenylglycine of $20 \%$ was reached after $3.0 \mathrm{~h}$ of reaction and the target product was obtained with an ee of $98 \%$. On the other hand, by using the less porous alginate beads (3.0\% $\mathrm{m} / \mathrm{v}$ ), the maximum production of D-phenylglycine achieved was half of that obtained in the former condition

Table 1. Production of D-phenylglycine using immobilized cells

\begin{tabular}{lcccc}
\hline & \multicolumn{2}{c}{$1.5 \%$ Sodium Alginate } & \multicolumn{2}{c}{$3.0 \%$ Sodium Alginate } \\
\cline { 2 - 5 } time/h & *Conversion/(\%) & ee/ $(\%)$ & $*$ Conversion/(\%) & ee/ $(\%)$ \\
\hline 0.5 & 1 & 98 & - & - \\
1 & 2 & 98 & 5 & 98 \\
2 & 7 & 98 & 5 & 98 \\
3 & 20 & 98 & 7 & 98 \\
4 & 18 & 98 & 10 & 98 \\
5 & 15 & 98 & 9 & 98 \\
\hline
\end{tabular}

*Percentage of conversion of 2-phenyl-2-amino-acetonitrile into D-phenylglycine.
$(10 \%)$ and with a longer reaction time, although the enantiomeric excess was the same (Table 1).

In order to test the operational stability of the biocatalyst, the cells entrapped with solution of sodium alginate $1.5 \%(\mathrm{~m} / \mathrm{v})$ were each one submitted to several cycle of D-phenylglycine production in a stirred batch reactor, lasting the time necessary to achieve maximal conversion (3 h). As depicted in Figure 4, in each cycle the catalytic activity of the entrapped cells remained unchanged so in each cycle maximal conversion was achieved in the same reaction time. A maximum of four reaction cycles were performed. This experiment suggests that the immobilization procedure of Pseudomonas aeruginosa 10145 in the interior of calcium alginate beads is a convenient one in order to produce D-amino acids using different amino nitrile substrates.

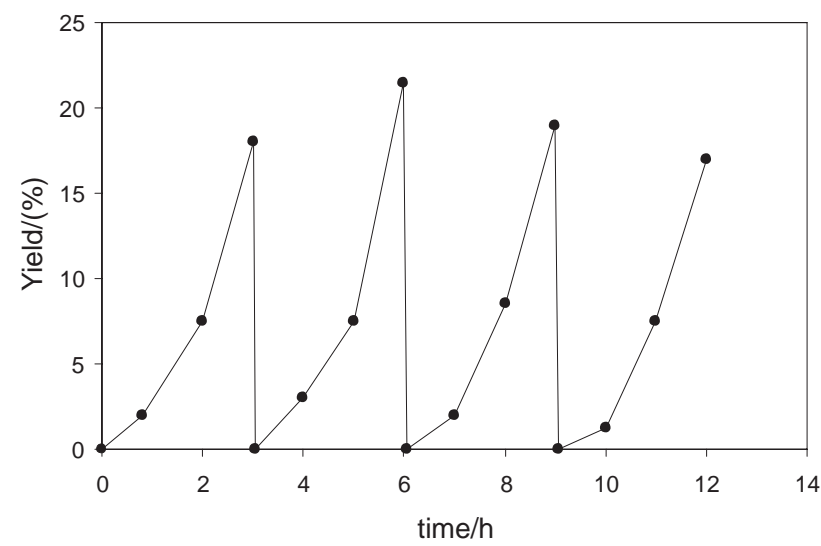

Figure 4. Repeated use of immobilized Pseudomonas aeruginosa 10145 cells in calcium alginate gel beads; $(\bullet)$ D-phenylglycine yield. Reactions conditions and analytical procedures are described under Materials and Methods.

\section{Acknowledgments}

This research was financially supported by CAPES, $\mathrm{CNPq}$ and FAPERJ. The bacterial strain was kindly donated by Dr. Ivano de Filippis from INCQS-Fundação Oswaldo Cruz-Rio de Janeiro-Brazil.

\section{References}

1. Becouarn, S.; Czernecki, S.; Valéry, J-M.; Tetrahedron Lett. 1995, 36, 873

2. Yagasaki, M.; Ozaki, A.; J. Mol. Catal.B: Enzym. 1998, 4, 1.

3. LeTiran, A.; Stables, J.; P; Kohn, H.; Bioorg. Med. Chem. 2001, 9, 2693.

4. Kondekar, N. B.; Kandula S. R. V.; Kumar, P.; Tetrahedron Lett. 2004, 45, 5477.

5. Matsumoto, H.; Hamawaki, T.; Ota, H.; Kimura, T.; Goto, T.; Sano, K.; Hayashi; Y.; Kiso, Y.; Bioorg. Med. Chem. Lett. 2000, 10, 1277 
6. Markoff, L.; Falgout, B.; Chang, A.; Virology 1997, 233, 105.

7. Ödman, P.; Wellborn, W. B.; Bommarius A. S.; Tetrahedron: Asymmetry 2004, 15, 2933.

8. Arcuri, M. B.; Sabino, S. J.; Antunes O. A. C.; Oestreicher, E. G.; J. Fluorine Chem. 2003, 121, 55.

9. Machado, G. D. C.; Gomes, Jr, M.; Antunes O. A. C; Oestreicher, E,G.; Process Biochem. (Amsterdam, Neth.) 2005, 40, 3186.

10. Kaul, P; Banerjee, A.; Mayilraj, S.; Banerjee, C. U.; Tetrahedron: Asymmetry 2004, 15, 207.

11. Graham, D.; Pereira, R.; Barfield, D.; Cowan, D.; Enzyme Microb. Technol. 2000, 26, 368.

12. Wegman, M. A.; Heinemann, U.; van Rantwijk, F.; Stolz, A.; Sheldon, R. A.; J. Mol. Catal. B. Enzym. 2001, 11, 249.

13. Brenner, C.; Curr. Opin. Struct. Biol. 2002, 12, 775.

14. Mascharak, P. K.; Coord. Chem. Rev. 2002, 225, 201.

15. Wieser, M.; Takeuchi, K.; Wada, Y.; Yamada, H.; Nagasawa, T.; FEMS Microbiol. Lett. 1998, 169, 17.

16. Vega-Hernández, M.; C; Léon-Barrios, M.; Pérez-Galdona, R.; Soil Biol. Biochem. 2002, 34, 665.

17. Snajdrová, R.; Kritová-Mylerová, V.; Crestia, D.; Nikolaou, K.; Kuzma, M.; Lemaire, M.; Gallienne, E.; Bolte, J.; Bezouska, K.; Kren, V.; Martínková, L; J.; Mol. Catal. B. Enzym. 2004, 29, 227.
18. Jianlong, W.; Liping, H.; Hanchang, S.; Yi, Q.; Chemosphere 2001, 44, 1041.

19. Kuncova, G.; Triska, J.; Vrchotova, N.; Podrazky, O.; Mater. Sci. Eng., C 2002, 21, 195.

20. Guo, X. L.; Deng, G.; Xu, J.; Wang, M. X.; Enzyme Microb. Technol. 2006, 39, 1.

21. Cassidy, M. B.; Lee, H.; Trevors, J. T.; J. Ind. Microbiol. 1996, 16, 79 .

22. Simpson, N. E.; Grant S. C.; Blackhand S. J.; Constantinidis, I.; Biomaterials 2003, 24, 4941.

23. Marques, M. A. S.; Pereira, H. M. G.; Aquino Neto, F.R.; J. Braz. Chem. Soc. 2006, 17, 382

24. Chilov, G. G.; Moody, H. M.; Boesten, W. H. J.; Sveda, V. K.; Tetrahedron: Asymetry 2003, 14, 2613

25. Arcuri, M. B.; Antunes, O. A. C.; Sabino, S. J.; Pinto, G. F.; Oestreicher, E.G.; Amino Acids 2000, 477.

26. Chen, C. S.; Fujimoto, Y.; Girdauskas, G.; Sih, C. J.; J. Am. Chem. Soc. 1982, 7294.

27. Machado, G. D. C.; Paiva, L. M. C.; Pinto, G.F.; Oestreicher, E. G.; Enzyme Microb. Tecnol. 2001, 322.

Received: August 30, 2006 Web Release Date: April 27, 2007 